\title{
Processing and Utilization of Tempe Liquid Waste to be Organic Fertilizer
}

\author{
Author \\ Okki Putra P., Wahyu Nursantoso, Fajar Adi N., Sigit Yunanda, M.Arifandi L., Andi Rahmad Rahim \\ Correspondence \\ Universitas Muhammadiyah Gresik \\ _galisantoso2@gmail.com, franky.another@gmail.com,gempo26@gmail.com,dan arifandi760@gmail.com
}

\begin{abstract}
The activities of KKN-Tematik program of Industrial Engineering Department conducted in Dukunanyar Village, Dukun Sub-district of Gresik Regency is to provide knowledge and implementation to Small and Medium Industry (IKM) tempe how to manage and utilize tempe liquid waste so as not to pollute the environment. Processing of tempe liquid waste using Adsorbtion method and filtering its function to neutralize liquid waste of tempe. Adsorption is a process of separating water from impurities by absorption of impurities such as fine particles, dissolved cations or odors contained in wastewater. The media used are zeloid stone, activated carbon and charcoal husk. Filtering is the process of irrigation or purification of water to produce clean water, free of odors, organic materials and inorganic materials contained therein. The media used are fibers, sand, and krikil. In addition to processing liquid waste tempe with adsorption method and filtering of liquid waste tempe can be utilized as Liquid Fertilizer Productive (PCP). Productive Liquid Fertilizer (PCP) is a way of utilizing tempe liquid waste with high organic content to improve soil chemical properties to be better so that the productivity of the plant has increased. For materials used in the manufacture of Liquid Fertilizer is liquid waste tempe and fluid starter EM4. By using appropriate tools for liquid waste processing and utilization of tempe liquid waste into a productive Liquid Fertilizer (PCP) on an ongoing basis can create the integration of appropriate waste treatment, and environmentally friendly.
\end{abstract}

Keywords: Processing and utilization, tempe liquid waste, adsorption method, starter EM4

Received: 30 November 2017. Accepted: 05 January 2018

\section{Introduction}

University of Muhammadiyah Gresik implements community service activity in form of Community Engagement Program (KKN). The activity aims to provide experience and knowledge about practical realities of the application of the discipline of science and theoretical. One kind of KKN activity is Thematic program which is implemented in Dukunanyar Village District Dukun.

Dukunanyar Village is one of the Villages among 26 Villages in Dukun Sub-districts of Gresik Regency. Dukunanyar village consists of 5 $\mathrm{RT}$ and $2 \mathrm{RW}$, and is located on the outskirts of Bengawan Solo river. Geographically in the north bordering Sembungan kidul and Sembunganyar Village, in the west by Kalirejo Village, Regency of Padang Bandung in the south, and Regency of Raci in the east Sidayu Sub-district.

One of the policy directions of Dukunanyar Village Government is to implement community empowerment through the development of small and medium enterprises, agriculture, farms and to tackling poverty. This is the background of the program that is made to help small and medium enterprises, especially small and medium Tempe industry in Dukunanyar Village manage and utilize Tempe liquid waste.

Tempe is a food made from soybean raw materials and the process is still simple and limited to the household scale. Tempe is recognized as a nutritious and inexpensive food that becomes a popular food community. Consumption tempe Dukunanyar village community is inseparable from the influence of socio-cultural conditions and behavior. In terms of raw materials, tempe made from soybeans (Glycinespp) and according to Sarwono (1989) that the production of soybeans in Indonesia more than half used for raw materials for making tempe and tofu. But now the obstacle that can threaten the survival of tempe business is the high price of soybeans. 
Almost in every city in Indonesia, including the city of Gresik found tempe industry which is generally still households and some of them entered in the container of Indonesian Cooperatives Tempe Home Industry (KOPTI) with the number of members reached 43.000 and INKOPTI as its parent (Herlambang, 2002). In general, liquid waste discharged into the river is not equipped with Wastewater Treatment Plant (WWTP). The higher the production of tempe will increase the volume of wastewater produced. Tempe liquid waste contains organic pollutants which, if not decomposed properly, will result in increased ammonia levels. The main source of ammonia comes from the decay of organic materials containing proteins, when the decomposition process (nitrification bacteria), the lack of oxygen in the water then the accumulation of ammonia becomes high, eventually will damage the river ecosystem and kill the aquatic organisms.

Ammonia has a negative impact on aquatic and human organisms if in excessive amounts. Zonneveld, Huisman and Boon (1991) stated that ammonia can cause the damage of fish gill tissue and at a ph of more than 8 ammonia absorbed in the blood will result in damage to the organ system of fish. The government established Kep - 51/ MENLH / 10/1995, as a quality standard where ammonia levels ranged from $1-5 \mathrm{mg} / \mathrm{L}$.

The amount of pollution loads caused serious disturbances, especially in waters around the tempe industry. Liquid waste produced from tempe industry prior to disposal into the environment must be processed first. It is intended that the liquid waste does not pollute the environment and the quality of healthy environment is maintained. Waste derived from processed food industry, is a fertile place for the development of microorganisms, especially microbial pathogens that multiply in water contaminated the emergence of various diseases. The quality of the environment depends on the quality of the environment itself with the record of providing optimal support for the survival of humans, animals and plants in a region.

Alternative waste treatment that can be done is to make the right tool to use adsorption and filtering methods. The material used in the manufacture of the right tool for processing tempeh liquid waste is plastic box, gauze, zeloid, carbon active, rice husk charcoal, palm fiber, sand and gravel.

In addition to treating tempe liquid waste by filtration method, liquid waste can also be utilized to be productive Liquid Fertilizer (PCP) by adding EM4 starter. Starter EM4 is a beneficial bacterium to fertilize soil and plants. The role of bacteria is binding nitrogen $(\mathrm{N})$, phosphorus $(\mathrm{Po})$, potassium

(K) and other elements for the needs of plants, so as to increase crop productivity. While the function of liquid waste tempe on the manufacture of liquid fertilizer is as a source of food for bacteria, so the bacteria will multiply themselves before the liquid fertilizer was used.

Programs tailored to the problems that occur in small and medium industry. Certainly, in terms of processing liquid waste Tempe is good. Outline of the output obtained from this program is the small and medium industry actors are getting knowledge about the processing of liquid waste is good so as not to pollute the environment. The hope is that business actors can implement the program results in a sustainable manner and provide changes to the environment. Thus, this program brings the benefits for the perpetrators of IKM Tempe and in general for the people of Dukunanyar Village.

\section{Literature Review}

\section{Tempe Industry}

According to Sumaatmadja (1988: 179) industry is a cultivation activity raw material into finished or semi-finished goods (manufacturing industry).

According to Kartasapoetra (1987: 6), industry is an economic activity that processes raw materials, raw materials, intermediate goods, and or finished goods into goods with higher value of use, including engineering and engineering activities.

According to of an industry is to process input into output. According to Adnan (2006: 1), Tempe is a traditional food of most people in Indonesia, which is loved by almost all levels of society. In addition to containing good nutrition, making Tempe or tofu is also relatively easy.

According to Adnan (2006: 1), Tempe industry in Indonesia has similar characteristics in each region, that is developing with small business capital, simple production technique, not prioritizing environmental sustainability factor, not 
yet able to process the waste generated, occupational safety and health is less attention and still lack of research and business development activities. For more details the production process Tempe can be seen in the chart below.

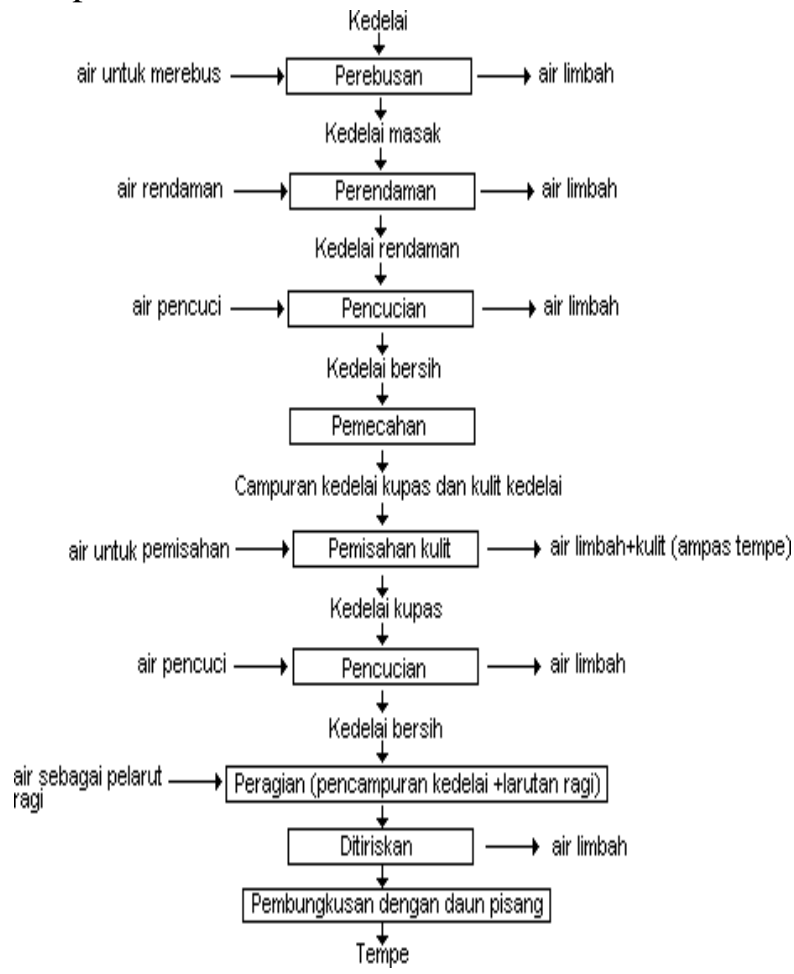

Figure 1. Flowchart Tempe production

\section{Impact Industry}

The industrial impacts are indirect and direct. According to Wardhana (2004: 20), indirect impacts of the industry are generally related to social issues of society, or more clearly disclosed

As for the direct impact (which is the nature negative) due to industrial activities and technology, can be seen from the occurrence of the following problems: a) air pollution, b) water pollution, c) terrestrial pollution.

Air pollution, water pollution, and terrestrial pollution can reduce the carrying capacity of nature, so it should be avoided as part of efforts to preserve the environment and environmental health.

\section{Environmental Health}

According to Widyati and Yuliarsih (2002: 2), environmental health is the controlling efforts of environmental conditions that may affect health, or which may cause harm to physical development, health and human survival.

Environmental health covers a very broad aspect covering almost all aspects of human life.
The importance of a healthy environment will affect human attitudes and behavior. According to Widyati and Yuliarsih (2002: 3)

\section{Waste Water Treatment}

According to Slamet (2000: 126) what is meant by wastewater is all water/liquid that is no longer used, although the quality may be good. Water used by humans for daily activities will be disposed of in a dirty and polluted form. In terms of environmental health and beauty, wastewater disposal issues need attention, both wastewater disposal in rural and urban areas.

According to Daryanto (1995: 22), one example of stages of waste water treatment process is as follows:

a. Primary handling, that is disposing of solid materials that precipitate

b. or floats.

c. Secondary handling, namely the decomposition process of biological solid materials

d. Precipitation, that is removing phosphorus components and suspended solids

e. Absorption, that is removing dissolved organic materials

f. Electrodialysis, that is lowering the concentration of dissolved salts up

g. at the original water concentration, before use

h. Chlorination, that is eliminating diseasecausing organisms

\section{Water pollution}

According to Wardhana (2004: 72) The water that is on earth is never in pure state, but there are always other compounds or minerals dissolved in it. This does not mean that all the water on this earth has been polluted. Water containing bacteria or microorganisms cannot be directly used as drinking water but must be boiled for bacteria and microorganisms to die. At certain limits drinking water is expected to contain minerals to make the water feel fresh. Pure water without minerals is not good to drink.

According to Wardhana (2004: 74), the indicator or sign that the environmental water has been polluted is a change or mark that can be observed through: 
a. The presence of changes in water temperature

b. The presence of changes in $\mathrm{pH}$ or Hydrogen ion concentration

c. The presence of changes in smell, color, and taste of water

d. The presence of sediment, colloidal, and soluble changes

e. The existence of micro-organisms

f. Increased environmental water radioactivity

\section{6. $\mathrm{Ph}$}

$\mathrm{pH}$ is the concentration of hydrogen ions $(\mathrm{H}+)$ in a liquid. Organisms in water very sensitive to changes in hydrogen ions. In the process of waterlogging, $\mathrm{pH}$ be an indicator to improve the efficiency of the cleansing process (Sutrisno, 1996: 73). $\mathrm{pH}$ is a term used to know the intensity of an acid or a base of a solution.

According to Wardhana (2004: 74), normal water that qualifies a life has a $\mathrm{pH}$ ranging from 6,5 to 7,5 waters can be acidic or alkaline depending on the size of the $\mathrm{pH}$. Water that has a $\mathrm{pH}$ smaller than normal $\mathrm{pH}$ will be acidic, while water having a $\mathrm{pH}$ greater than normal $\mathrm{pH}$ will be alkaline. Wastewater and waste materials from industrial activities dumped into the river will change the $\mathrm{pH}$ of water which ultimately disrupts organism life (Sutrisno, 1996: 73). $\mathrm{pH}$ is a term used to determine the intensity of an acid or base of a solution

\section{Biological Oxygen Demand}

Biological Oxygen Demand or BOD demand is the amount of oxygen required by microorganisms in the water environment to break down (degrade) organic waste in the water the environment (Wardhana, 2004: 93). The BOD value does not show the actual amount of organic material, but only measures the relative amount of oxygen required to chemically oxidize the waste materials. If high oxygen consumption is indicated by the smaller residual dissolved oxygen, then the organic materials present require high oxygen (Pandia, et al 1996: 43).

\section{Total Suspended Solid}

Total Suspended Solid is the amount of solid that is not dissolved in water caused by the presence of inorganic elements in water (Muttalib,
1994: 12). If the solid waste material dissolves in water, then the water density or the specific gravity of the liquid will increase. Sometimes solid waste materials in water will be accompanied also by changes in water color, consequently the process of photosynthesis of plants in the water will be disrupted. The amount of dissolved oxygen will be reduced. This matter of course also affects the life of organisms that live in the water (Wardhana, 2004: 79).

\section{Environment}

Human interaction with the environment is a natural process and it is done since the human being was born until he died. It occurs because humans need the carrying capacity of environmental elements for their survival

According to Slamet (2000: 18), that the environmental affects the occurrence of the disease has long been predicted people. For example, the name "Malaria" which means bad air, is given to a disease that has symptoms of fever, chills, sweating, fever again, chills again, and so on, and is found among the resident population around the swamp.

\section{Physical Environment}

According to Bintarto (1979: 22) the physical environment is everything around human death like the mountains, rivers, water, sunshine, vehicles, houses, and so forth. In this study the physical environment in question is the river, industrial waste water Tempe, waste water that flowed into the river and water wells located in the village Dukunanyar.

\section{Social environment}

According to Bintarto (1979: 22) the social environment has several aspects such as civic attitude, mental attitude, and spiritual attitude. In this study the social environment that is studied is a social attitude, which in this case is the attitude of society is the effort made by the community in Dukunanyar Village to the impact of the existence of Tempe industry in the form of waste and solid waste.

\section{Method}

Before the implementation of the work program, first survey and observation of the 
location of owners of Small and Medium Industry Tempe (IKM) in the village of Dukunanyar was conducted. Survey and observation is done to find out the problems faced by IKM Tempe owner, so we can know the appropriate solution.

\section{Problem Review}

Broadly speaking the problem faced by Small and Medium Industry (IKM) Tempe in Dukunanyar Village is the lack of innovations in processing and utilization of tempe liquid waste. Tempe liquid waste containing organic pollutants comes from decomposition of organic materials containing proteins when the process of decomposition, the lack of oxygen in the water then the ammonia accumulation becomes high, eventually will damage the river ecosystem and kill the aquatic organisms. During this Tempe liquid waste can only be dirt and even garbage in the waters that are very detrimental to the environment, but if done processing and utilization optimally will be very profitable and it is still rare people who know.

\section{Identification}

\section{Problems}

- Lack of knowledge about the dangers when the Tempe liquid waste is discharged directly into the environment

- Difficulty in processing and utilization of Tempe liquid waste
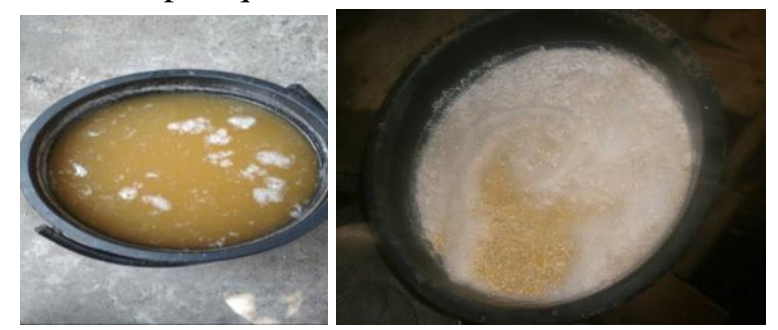

Figure 1. Tempe liquid waste in bucket

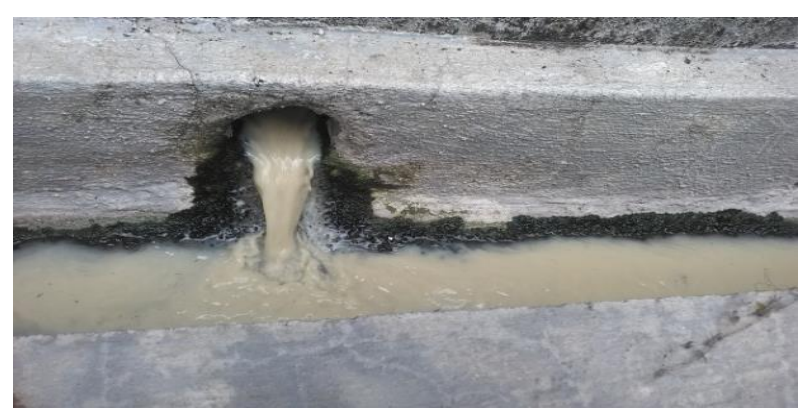

Figure 2. Tempe liquid waste thrown into a ditch

\section{Needs:}

- The right tool for processing tempeh liquid waste.

- Utilize liquid waste Tempe into a product

\section{Activity:}

- Provide socialization about the dangers posed when the effluent is discharged directly into the river

- Provide information about the processing and utilization of liquid waste production of the right and effective Tempe

- Provide the right tool for the effluent treatment of Tempe wastewater production.

- Provide assistance on how to use liquid waste into productive Liquid Fertilizer (PCP)

\section{Definition and Approach}

Broadly speaking the program activities is constructed based on the emerging problems faced by Small and Medium Industry Tempe is the processing and utilization of Tempe liquid waste. Waste is the waste of a production process or domestic (household). Waste consists of liquid, solid and gas wastes. Negative impacts include air pollution, water pollution, soil contamination, greenhouse effect, increased geothermal and acid rain (Chynoweth, 2001).

Another limitation is that wastewater is a combination of liquid and liquid waste coming from settlements, commerce, offices and industries, together with groundwater, rainwater and rainwater that may exist (Haryoto, 1985). From these limits it can be concluded that the waste water is the remaining water from human activities, both household activities and other activities such as industry, hotels and so on.Therefore, this waste water must be processed properly in order to maintain water quality.

Waste has inorganic and organic characteristics that can still be used and reused to reduce the negative impact of waste. The processing of solid waste, liquid and gas is one solution to reduce the negative impact caused by the waste. To improve the quality of the environment, it is necessary to do waste treatment in order to neutralize the harmful substances contained in the waste. In addition, the waste treatment system also needs to be considered 
in order to create the integration of appropriate waste treatment, and environmentally friendly.

Processing of tempeh liquid waste with appropriate tools using adsorption and filtering method as innovation in river pollution control. Given the right tools are easy, simple, economical, environmentally friendly, as well as the maximum work and result in overcoming the river water pollution caused by liquid waste tempe so that the quality of river water to be better.

Utilization of tempe liquid waste is to make it as liquid fertilizer commonly known as Productive Liquid Fertilizer (PCP). Productive Liquid Fertilizer (PCP) from tempe liquid waste has a high organic content to improve soil chemical properties so that soil quality is better so that the productivity of the plant has increased.

\section{Activity Implementation Method Preparation}

1) Prepare material on the dangers of tempe liquid waste discharged into the Powerpoint Slide form environment

2) Prepare material on the processing and utilization of the right tempe liquid waste and effective form of Slide Powerpoint

3) Print Powerpoint Slide documents and questionnaires

\section{Socialization}

Visits to Small and Medium Industry (IKM) Tempe with resource persons from the Office of Koperindag Miss. Olin Lintang to provide socialization about the dangers of tempe liquid waste when disposed of directly into the river and appropriate effluent treatment.

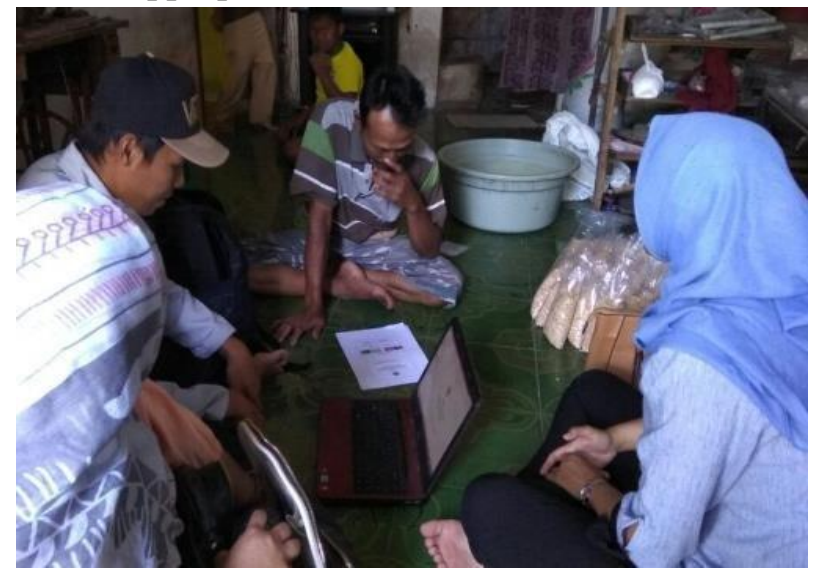

Figure 3. Direct socialization at home industry of IKM Tempe with resource persons

\section{Planning activities}

Planning activities can be done after we visited or survey the owners of Small and Medium Industry (IKM) tempe located in the village Dukunanyar. We interviewed the problems faced by IKM Tempe. In order for this program to run optimally, it requires proper planning. Here's the planning we made:

1) Contacting Tempe business actor at the residence of Mr. Syarifudin RT.01 / RW 01 Dukunanyar Village, Dukun Sub-District, Gresik Regency

2) Contacting resource persons from the Office of Koperindag Mrs. Olin Lintang for direct counseling to Small and Medium Industry (IKM) Tempe.

\section{Implementation}

Activities carried out on:

- Dated August 19, 2017

- 13.30 - 16.30, place

- Home industry of IKM Tempe

\section{Engineering implementation}

The activity is carried out by direct counseling to IKM Tempe. The implementation stages are:

1) Identify problems of IKM Tempe

2) Counseling on the dangers of Tempe liquid waste directly discharged into the environment, as well as the proper and effective way of processing and utilizing wastewater.

3) Providing information on the problems faced by IKM Tempe owners

4) Provision of alternative solutions for IKM Tempe in accordance with the needs

5) Providing questionnaires as an assessment indicator

\section{Alternative solution}

Provide alternative solutions from the subject matter after the counseling.

1. Processing of tempe liquid waste using adsorption and filtering method.

Adsorption is a process of separating water from impurities by absorption of impurities such as fine particles, dissolved cations or odors contained in wastewater. The adsorption medium used in wastewater 
treatment is activated activated zeloit rock and rice husk charcoal. Activated carbon can be made from any ingredient that can be made as activated carbon. But the most common is the activated carbon from the coconut shell. Activated zeloid stone can be purchased on the market. While rice husk charcoal is obtained by making carbon active zeloit stone and rice husk charcoal has properties as an adsorbent so as to absorb the particles or cations and odors that dissolved or mixed in waste water.

Filtering is the process of irrigation or purification of water to produce clean water, free of odors, organic materials and inorganic materials contained therein. The media used are fibers, sand and gravel. Technique of making the right tool for liquid waste treatment of materials used is plastic box that is given faucet at the bottom, gauze sealing cloth, zeloit stone, activated carbon, charcoal husk, palm fiber, sand and gravel.

The process of making tools are:

- insert the gauze into a box box of 20 liters.

- insert gravel

- input the screen as an insulator

- enter the sand

- insert the screen

- insert the fibers

- insert the screen

- insert chaff charcoal

- insert the screen

- insert the activated carbon

- insert the screen

- zeloit stone input and

- insert the screen

The following is the right tool to process Tempe liquid waste.

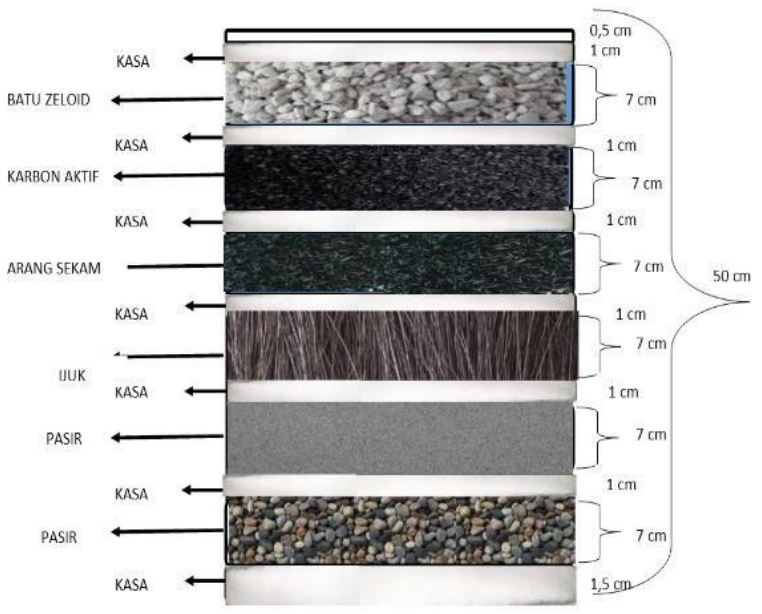

Figure 4. Process Tempe liquid waste

The waste that is on the appropriate means of waste treatment undergoes filtration steps. The initial stage of screening will be through a functioning gauze to filter dissolved waste that will not precipitate, then it will enter the zeloid stone media and activated carbon that serves to absorb the particles or cations and odors dissolved or mixed in wastewater, then through rice husk charcoal fungi absorb substances that contaminate water and absorb odors and colors, then through fibers that functionally filter the particles present in the liquid waste will be retained by the fibers, then through the sand that serves to filter micro-sized objects, and finally will pass through the gravel that serves as the final filter before the waste water is discharged into the river

2. Utilization of tempe liquid waste into Productive Liquid Fertilizer (PCP).

PCP from tempe waste serves to improve soil chemical properties so that soil quality is better so that the productivity of the plant has increased. Technique of making Productive Liquid Fertilizer (PCP). Prepare materials used such as Buckets for liquid waste containers taken from tempe industry, Liquid Waste of boiled tempe, EM4 starter, and 5 liter jerry for container of Productive Liquid Fertilizer (PCP). PCP manufacturing process that is:

a) Prepare liquid waste tempe from soybean stew as much as 10 liters

b) Prepare a bucket of 20 liters 
c) The hot waste is put into the bucket and then cooled

d) After cool add starter EM4 as much as 5$10 \%$

e) Liquid wastes that have been added starter EM4, then packed into a 5-liter sized jerigenyang then stored at room temperature for 7 days. The EM4 starter contains a useful bacterial population.

f) Liquid fertilizer is successful if opened when it smells like urea

g) Tempe liquid fertilizer is ready to be used to fertilize the soil around the plant.

h) If not already used in the near term, you should add 3\% EM4 starter.

\section{Evaluation}

From the execution of the program we can report that has been running well. The response of Tempe industry owners is quite good to the program and very helpful in the processing of waste in Tempe industry. Preparation of appropriate tools for processing liquid waste tempe and productive liquid fertilizer is motivated by the desire to utilize industrial liquid waste tempe in the village Dukunanyar. Tempe industrial liquid waste can not be treated properly so it can pollute the environment. So far, only liquid waste discharged into waters near tempe industry.

Alternative treatment of Tempe liquid waste with the right tools and make Tempe liquid waste into liquid fertilizer is a solution to prevention of environmental pollution. Liquid waste obtained from tempe industry of Dukunanyar village RT.01 / RW.01. Then do the processing using appropriate tool and making productive liquid fertilizer. Furthermore, the activities of socialization and coaching in Tempe industry. Monitoring activities were conducted with assistance to Tempe industry during the KKN period.

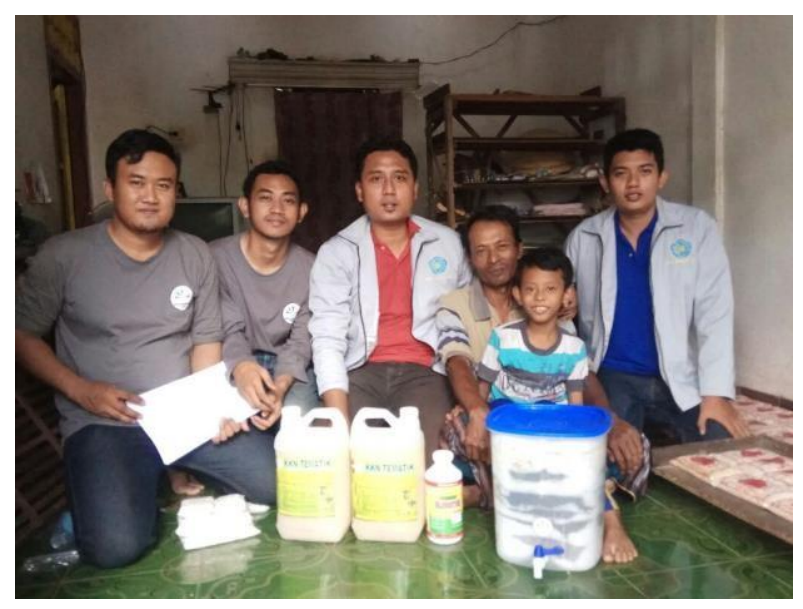

Figure 5. Coaching waste treatment

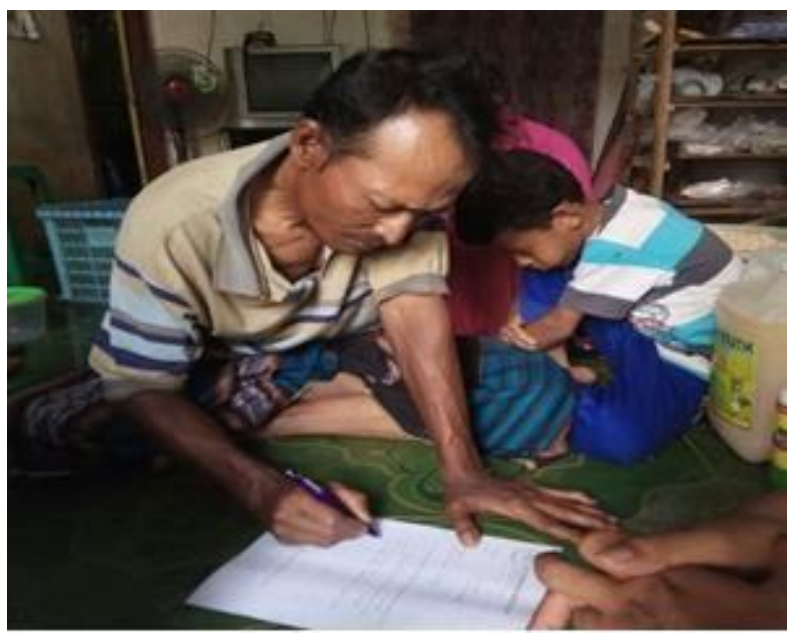

Figure 6. Assistance activities

\section{Result and Discussion \\ Result}

The results of our work program are as follows:

\section{Processing of Tempe liquid waste}

Making the right tool for liquid waste treatment by adsorption and filtering method that can neutralize the harmful content, filtering small particles, lowering the odor and color levels to produce environmentally friendly waste water. This is very positive for the development of the right tool for processing Tempe liquid waste in a larger direction, in addition to the economical tools are easily applied. Efficient tools using adsorption and filtering methods have good effectiveness to process industrial waste of Tempe so that pollution load due to Tempe liquid waste can be reduced to environmentally friendly. 


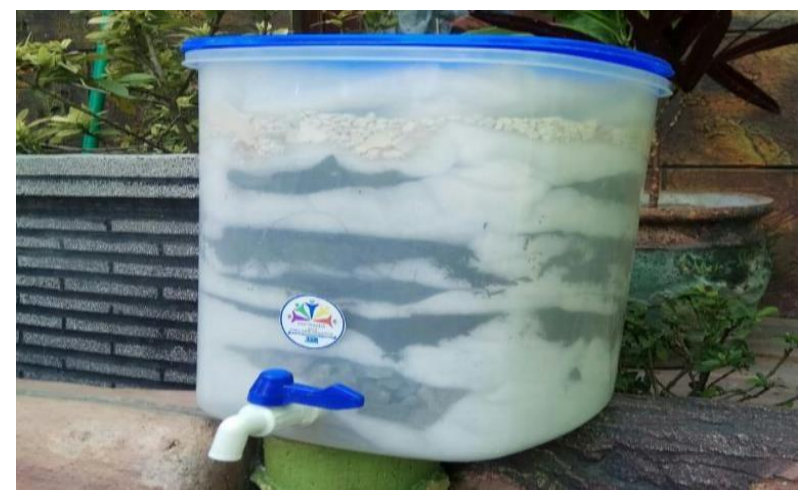

Figure 7. Waste processing

\section{Utilization of Tempe liquid waste}

Utilization of liquid waste Tempe into Liquid Productive Fertilizer ( $\mathrm{PCP}$ ) is the right way to create a byproduct of Tempe industry. To provide value added toward wastewater that was originally just as waste and dumped into the river. The result of this program is Tempe industry get help how to use waste into Liquid Productive Fertilizer (PCP), so that can reduce the environmental pollution caused by liquid waste Tempe. IKM Tempe get sample product Liquid Productive Fertilizer (PCP) from waste of Tempe

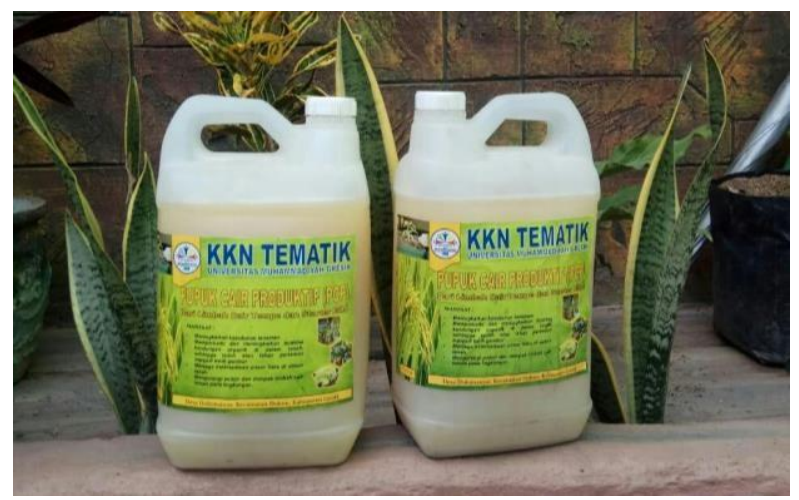

Figure 8. Liquid Fertilizer Product (PCP)

\section{Discussion}

Activities undertaken at IKM in Dukunanyar Village, Dukun Sub-district of Gresik Regency are socialization about the dangers of tempe liquid waste directly disposed into the river and proper and effective waste water treatment of tempe, together with the source of Mrs. Olin from Koperindag, the activity begins by communicating the implementation and technical time activities in the field with the Koperindag Office a few days earlier.

Activity in the field begins with a visit to the IKM tempe, where at the socialization session in getting some important points that become minus points on IKM tempe such as:

a. Lack of knowledge about the dangers of tempe liquid waste.

b. Tempe Liquid Waste that has not been utilized. During this time only wasted and pollute the environment.

Having known the minus points in the Tempe IKM team from KKN thematic 12 initiative to give some input such as:

1) Wastewater treatment by making the right tool using adsorption and filtering method was able to neutralize the dangerous content, filtering small particles, lowering the odor and color levels to produce environmentally friendly waste water. This is very positive for the development of the right tool for processing tempeh liquid waste in a larger direction, in addition to the economical tools are easily applied.

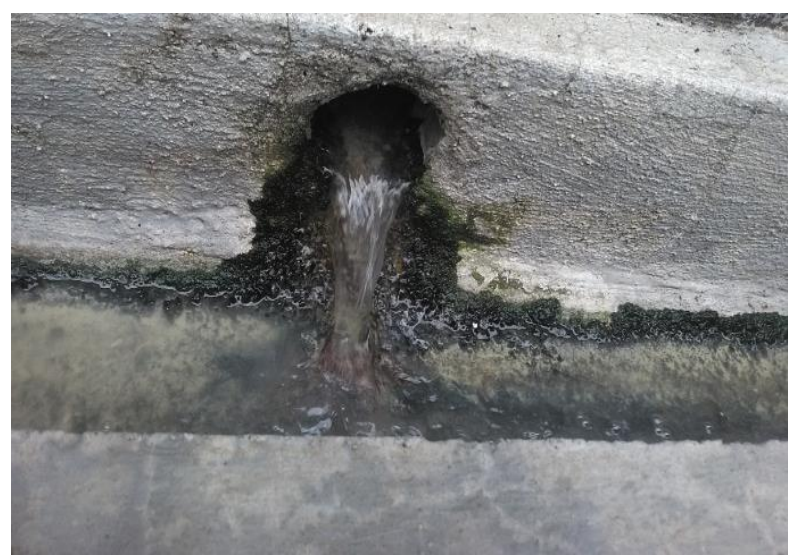

Figure 9. IKM eco-friendly waste

2) Utilization of tempe liquid waste into Productive Liquid Fertilizer (PCP) is the the right way to create byproducts from tempe industry. So as to provide added value to liquid waste that was originally only as waste and dumped into the river.

\section{Conclusions and Suggestions Conclusion}

Tempe Liquid Waste that is not processed first and then discharged into the river, has great potential in causing river pollution. Processing by using adsorption and filtering methods is simple and does not cost much. Creating simple tools to use simple adsorption and filtering methods 
composed of several components that have an effective function in binding the hazardous content of Tempe liquid waste, and can neutralize the odor and color of waste. In addition to processing liquid waste Tempe can also be used as a productive Liquid Fertilizer (PCP) by adding an EM4 starter.

However, the effort to process and utilize Tempe liquid waste has not been maximized because of the lack of knowledge of Tempe industry entrepreneurs in the way of processing and utilizing the appropriate and effective liquid waste, so that the Tempe liquid waste is only disposed of the river and ignored. This resulted in pollution of river water, killing biota in the river, and disrupt the settlement of people who are in the watershed because the waste can cause unpleasant odors and potential diseases.

\section{Suggestion}

Processing of industrial wastewater of tempe with adsorption and filterrisation method into innovation control of river water pollution that is environmentally friendly and renewable, it is expected that tempe industry actors use the appropriate tools with adsorption and filtering method continuously, so that tempe industry become environmentally friendly industry.

Utilization of industrial liquid waste Tempe into Liquid Productive Fertilizer (PCP) is the right way to create side products from tempe industry. So that industrial liquid waste tempe can provide added value for Tempe industry players.

\section{Acknowledgments}

This report is prepared as one of the assessment of the whole program of community engagement program and to know how far the student activity program in executing KKN can be realized well. With the aim to do community service, we hope that all KKN programs that have been run can be beneficial for both parties

We realize that the implementation of the Real Work Lecture and the preparation of this report can not be separated from the guidance, encouragement and assistance both material and non-material from various parties, so that the programs that have been planned can be realized properly and can be completed in a timely manner. Therefore let us express our gratitude to:
1. Allah Almighty, who is always there in every step, for his gifts, guidance, mind, mind, strength, health and all his ease.

2. Father and Mother, thanks for the prayer because with prayer it can spread the wings of millions of angels to protect our every step.

3. Implementing Agency for community engagement program (KKN) of Muhammadiyah University Gresik

4. Mr. Rector of the University of Muhammadiyah Gresik the opportunity to the author to implement the community engagement program.

5. The head of Village and Village Community of Dukun Anyar Dukun Sub-district of Gresik Regency, thank you very much for all the help and cooperation so that this community engagement program can run smoothly.

6. All parties who have participated and provide support both material and nonmaterial that can not authors mention one by one.

Hopefully from all assistance, guidance and consultation that has been given to us get rewarded from Allah SWT. We express our apology if during carrying out the task of KKN there are errors and mistakes. We are fully aware of the limitations of our capabilities. Therefore, we expect criticism and constructive suggestions for the improvement of community engagement practices.

\section{References}

Adnan., G. (2006). Pemanfaatan dan Pengolahan

Limbah Tahu Tempe. Yogyakarta: Kementrian Lingkungan Hidup.

Azhari, M. (2016). Pengolahan Limbah Tahu dan Tempe dengan Metode Teknologi Tepat Guna Saringan Pasir sebagai Kajian Mata Kuliah Pengetahuan Lingkungan. Vol. 1 No. 2, pp. 1-8. Fredi, e. (2009). Program Kreatifitas Mahasiswa Pengolahan Limbah Cair Tempe Menjadi Pupuk Cair Produktif (PCP) Despansar: Universitas Udayana.

Herlambang, A. (2002). Pengaruh Pemakaian Biofilter Struktur Sarang Tawon pada Pengolah Limbah Organik Sistem Kombinasi Anaerobik- 
Aerobik (Study kasus limbah tahu dan tempe disertasi program pasca Sarjana IPB0 Bogor. 304 hal.

Huisman dan J.H. Boon. (1991). Prinsip - Prinsip Budidaya ikan. Jakarta: PT. Gramedia Pustaka Utama.

Idaman, N. d. (1999). Teknologi Pengolahan Air Limbah Tahu-Tempe dengan Proses Biofilter Anaerob dan aerob Jakarta: Direktorat Teknologi Lingkungan, Deputi Bidang Teknologi Informasi, Energi Material dan Lingkungan. .

Jakarta, A. M. (n.d.).

Jakarta, S. 2. (2001). Pelestarian Sumber Daya Tanah dan Air. Jakarta: Rineka Cipta.

Kristanto., P. (2002). Ekologi Industri. Jakarta:

Raja Grafindo Persada.

Lidyani, P. (2011). Sukses Membuat Pupuk Cair. Jakarta: Bentara Cipta Prima.

Malang., R. R. (2008). Pengaruh Pemberian Air Limbah Tempe Sebagai Pupuk Organik terhadap pertumbuhan dan hasil tomat. Malang: UIN.

(n.d.). Mentri Negara Lingkungan Hidup, Keputusan Mentri Negara Lingkungan Hidup Nomor : Kep-51/MENLH/10/1995, tentang Pedoman Penetapan Baku Mutu Lingkungan.

Muthalib, A. (1994). Dasar Penetapan Dampak Kualitas Air. Departemen Kesehatan RI. Jakarta.

Priyanto, s. 2. (2008). Pelatihan Pembuatan Pupuk Cair Dari Limah Tempe Di Desa Pliken Kecamatan Kembaran Banyumas.

Rahmah, N. (2011). Studi pemanfaatan limbah cair tahu untuk pupuk cair tanaman. Surabaya: ITS.

RPJM DES 2014 - 2019. Rencana Pembangunan Jangka Menengah Desa Dukunanyar.

Sampe, H. (2013). Pencemaran Perairan Akibat Kadar Amoniak yangTinggi Dari Limbah Cair Industri Tempe. Jurnal Akuatika, Vol. IV No. 183-194.

Sinaga, D. (2009). Pembuatan Pupuk Cair dari Sampah Organik dengan Menggunakan Biosca Sebagai Starte. Medan: USU.

Slamet., J. S. ( 2000). Kesehatan Lingkungan. Jakarta: Gadjah Mada University Press.

Sugiharto, 1. D.-D. (1987). Dasar-Dasar Pengelolaan Air Limbah. Jakarta: Universitas Indonesia.
Suripin. (2001). Pelestarian Sumber Daya Tanah dan Air. Jakarta: Rineka Cipta.

Totok Sutrisno, d. (2002). Tekhnologi Penyediaan Air Bersih. Jakarta: Rineka Cipta.

Wardhana, W. A. (2004). Dampak Pencemaran Lingkungan. Yogyakarta.: Andi Yogyakarta.

Wiryani, E. 2. (2010). Analisis Kandungan Limbah Cair Pabrik Tempe. Jurnal Sainteks. Semarang: Lab. Ekologi dan Biosistematik FMIPA, UNDIP.

Zonneveld N, E. A. (1991). Prinsip - Prinsip Budidaya ikan. Jakarta: PT. Gramedia Pustaka Utama. 